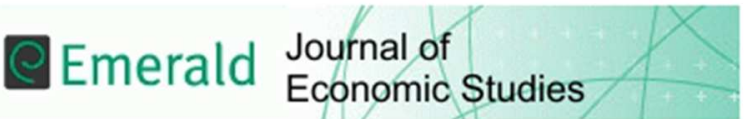

\section{THE WEEKEND EFFECT: AN EXPLOITABLE ANOMALY IN THE UKRAINIAN STOCK MARKET?}

\begin{tabular}{|r|l|}
\hline Journal: & Journal of Economic Studies \\
\hline Manuscript ID & JES-09-2015-0167.R1 \\
\hline Manuscript Type: & Research Paper \\
\hline Keywords: & Ukraine, weekend effect, trading \\
\hline & \\
\hline
\end{tabular}

SCHOLARONE ${ }^{\text {m }}$

Manuscripts 


\title{
THE WEEKEND EFFECT: \\ AN EXPLOITABLE ANOMALY \\ IN THE UKRAINIAN STOCK MARKET?
}

\begin{abstract}
This paper provides some new empirical evidence on the weekend effect (one of the best known anomalies in financial markets) in Ukrainian futures prices. The analysis uses various statistical techniques (average analysis, Student's ttest, dummy variables, and fractional integration) to test for the presence of this anomaly, and then a trading simulation approach to establish whether it can be exploited to make extra profits. The statistical evidence points to abnormal positive returns on Fridays, and a trading strategy based on this anomaly is shown to generate annual profits of up to $25 \%$. The implication is that the Ukrainian stock market is inefficient.
\end{abstract}

Keywords: Efficient Market Hypothesis; Weekend Effect; Trading Strategy.

JEL classification: $G 12, C 63$ 


\section{Introduction}

Since Fama (1970) introduced the Efficient Market Hypothesis (EMH), the behaviour of asset prices has been extensively investigated to establish whether it is consistent with this paradigm. One of the best known anomalies is the so-called "day of the week" or weekend effect. Cross (1973) reported that asset prices tend to increase on Fridays and decrease on Mondays. A number of subsequent papers have tested for this anomaly (see, e.g., Sias and Starks, 1995; Schwert, 2003; Olson et al., 2011; Kazemi et al. 2013)) providing mixed evidence, but none has looked at the Ukrainian stock market, which is the focus of the present study. Specifically, the analysis uses various statistical techniques (average analysis, Student's t-tests, dummy variables, and fractional integration) to test for the presence of this anomaly, and then a trading simulation approach to establish whether it can be exploited to make extra profits.

The layout of the paper is as follows. Section 2 briefly reviews the literature on the weekend effect. Section 3 describes the data and outlines the empirical methodology. Section 4 presents the empirical results. Section 5 offers some concluding remarks.

\section{Literature Review}

Cross (1973) analysed Standard \& Poor's Composite Stock Index data from January 1953 to December 1970 and claimed to have found some patterns in the behaviour of US asset prices, namely an increase on Fridays and a decrease on Mondays. French (1980) extended this analysis to 1977 and reported negative returns on Mondays. Gibbons and Hess (1981), Keim and Stambaugh (1984), Rogalski (1984) and Smirlock and Starks (1986) also found the positive-Friday / negative-Monday pattern. Agrawal and Tandon (1994) examined 19 equity markets around the world, and found the "day of the week" effect in most developed markets. Further evidence was provided by Olson et al. (2011), Racicot (2011), Singal and Tayal (2014), and Caporale et al. (2014), who found some evidence of a weekend effect in 
the US stock market, FOREX, and commodity markets as well as in the Russian stock market; in particular, fractional integration techniques suggest that the lowest orders of integration occur on Mondays.

Possible explanations for the weekend effect are: the psychology of investors who believe that Monday is a "difficult" day of the week and have a more positive perception of Friday (Rystrom and Benson, 1989); the closing of speculative positions on Fridays and the establishing of new short positions on Mondays by traders (Kazemi et al., 2013 and Chen and Singal, 2003), and the trading patterns of institutional investors (Sias and Starks, 1995). Another possible reason is that over the weekend market participants have more time to analyse price movements and, as a result, on Mondays a larger number of trades takes place. Alternatively, this might be due to deferred payments during the weekend, which create an extra incentive for the purchase of securities on Fridays, leading to higher prices on that day.

Evidence that the weekend effect has become less important over the years has been reported by Fortune (1998, 1999), Schwert (2003), and Olson et al. (2011). Further, Caporale et al. (2014) show that this anomaly cannot be exploited to make abnormal profits (and therefore it is not inconsistent with the EMH) by taking a trading robot approach.

\section{Data and Methodology}

We use daily data for UX index futures. The sample covers the period from May 2010 (the first available observation) to the end of December 2014. The data source is the Ukrainian Exchange (http://www.ux.ua/en/).

To examine whether there is a weekend effect we use the following techniques:

- $\quad$ average analysis

- Student's t-tests 
- $\quad$ regression analysis with dummy variables

- $\quad$ fractional integration tests

Average analysis provides preliminary evidence on whether there are differences between returns on different days of the week. Student's t-tests are carried out for the null hypothesis that returns on all days of the week belong to the same population; a rejection of the null implies a statistical anomaly in the price behaviour on a specific day of the week. Given the size of our dataset, it is legitimate to argue that normality holds on the basis of the Central Limit Theorems (see Mendenhall, Beaver and Beaver, 2003), and therefore these are valid statistical tests. As a further check for normality, we also apply Pearson's criterion: we randomly select 100 consecutive price returns for the period 2014 (Table 1) and calculate the critical value of the distribution. These confirm that the data are normally distributed and therefore Student's t-tests are valid, since their critical values do not exceed those of the chi-square distribution.

Table 1: "Normality" test of the UX index futures data

\begin{tabular}{|l|c|}
\hline \multicolumn{1}{|c|}{ Parameters } & Values \\
\hline Observations & 100 \\
\hline Average & 1233 \\
\hline Standard deviation & 65 \\
\hline Confidence level & 0.95 \\
\hline Chi-square values & 8.98 \\
\hline Chi-square distribution critical value $\left(h i_{(p=0.95, f=5)}\right)$ & 11 \\
\hline Conclusion & $\begin{array}{c}\text { Data are normally } \\
\text { distributed }\end{array}$ \\
\hline
\end{tabular}

The t-statistic is calculated as follows:

$$
t=\frac{\left|M_{1}-M_{2}\right|}{\sqrt{\frac{\sigma_{1}^{2}}{N_{1}}+\frac{\sigma_{2}^{2}}{N_{2}}}}
$$

where $M_{1} \quad-\quad$ mean of the population of returns on the day whose effects are being tested; 
$M_{2} \quad-\quad$ mean of the population of all returns except the observations on the day whose effects are being tested;

$\sigma_{1} \quad-\quad$ standard deviation of the population of returns on the day whose effects are being tested;

$\sigma_{2} \quad-\quad$ standard deviation of the population of all returns except the observations on the day whose effects are being tested;

$N_{1} \quad-\quad$ size of the population of returns on the day whose effects are being tested;

$N_{2} \quad-\quad$ size of the population of all returns except the observations on the day whose effects are being tested; ${ }^{1}$

The test is carried out at the $95 \%$ confidence level, and the degrees of freedom are $\mathrm{N}-1$ ( $\mathrm{N}$ being equal to $\mathrm{N}_{1}+\mathrm{N}_{2}$ ).

Returns are computed as follows:

$$
\mathrm{R}_{\mathrm{i}}=\left(\frac{\text { Close }_{\mathrm{i}}}{\text { Open }_{\mathrm{i}}}-1\right) \times 100 \%
$$

\section{where $R_{i} \quad-\quad$ UX index futures returns on the $i$-th day in $\%$;}

Open $_{i}-\quad$ open price on the $i$-thday;

Close $_{i}-\quad$ close price on the $i$-thday.

We also run multiple regressions including a dummy variable for each day of the week, specifically:

$$
\begin{aligned}
& \mathrm{Y}_{\mathrm{t}}=\mathrm{b}_{0}+\mathrm{b}_{1} \text { Monday }_{\mathrm{t}}+\mathrm{b}_{2} \text { Tuesday }_{\mathrm{t}}+\mathrm{b}_{3} \text { Wednesday }_{\mathrm{t}}+\mathrm{b}_{4} \text { Friday }_{\mathrm{t}}+\varepsilon_{\mathrm{t}} \\
& \text { where }
\end{aligned}
$$$$
Y_{t} \text { - difference between average returns during a week and the day of the week }
$$
whose effects are being tested;

\footnotetext{
${ }^{1}$ This is the day which is being analysed for the presence of an anomaly.
} 
$\mathrm{b}_{0}$ - difference between average returns during a week and on Thursdays (this is chosen as a typical day of the week, no anomalies in price behaviour have previously been detected on this day);

$b_{n}-$ difference between average returns on the $n$-th day of the week included in the model and on Thursdays;

Monday $_{\mathrm{t}}$ - dummy variable for Monday, equal to 1 on that day of the week, and 0 otherwise.

The size, sign and statistical significance of the dummy coefficients provide information about possible anomalies on individual days of the week.

As an additional test, we estimate the degree of integration of the series for different days of the week. Specifically, we use the Whittle function in the frequency domain (Dahlhaus, 1989) in the following model:

$$
y_{t}=\alpha+\beta t+x_{t} ; \quad(1-L)^{d} x_{t}=u_{t},
$$

where $y_{t}$ is the observed time series; $\alpha$ and $\beta$ are the intercept and the coefficient on the linear trend respectively, $x_{t}$ is assumed to be an $I(d)$ process where $d$ can be any real number, and $\mathrm{u}_{\mathrm{t}}$ is assumed to be weakly $\mathrm{I}(0)$ autocorrelated. Rather than specifying a parametric ARMA model, we follow the non-parametric approach of Bloomfield (1973), which also produces autocorrelations decaying exponentially as in the AR case. If the estimated order of integration for a particular day, specifically Monday or Friday, is significantly different from that for the other days of the week, then it can be argued that there is evidence of a weekend effect.

Finally, having tested for possible weekend effects, we examine whether they give rise to exploitable profit opportunities by means of a trading simulation approach. Specifically, we use an algorithm based on the weekend effect to replicate the behaviour of a trader who opens positions on the UX futures and holds them for a certain period of time. 
We use the following procedure to simulate the trading process. First we compute the percentage result of the deal:

$$
\% \text { result }=100 \% \times P_{\text {open }} / P_{\text {close }}
$$

where

$$
\begin{aligned}
& P_{\text {open }}-\text { opening price } \\
& P_{\text {close }}-\text { closing price }
\end{aligned}
$$

Then this difference is converted into Ukrainian hryvnas (UAH).

$$
U A H \text { result }=\% \text { result } \times 1000
$$

where $U A H$ result - is result of the deal in $\mathrm{UAH}$.

The sum of results from each deal in UAH is the total financial result of trading.

A strategy resulting in a number of profitable trades $>50 \%$ and positive total profits is defined as indicating an exploitable market anomaly.

\section{Empirical Results}

We start with some simple average analysis. The results are displayed in Figure 1.

Figure1: Average returns by days of the futures on UX index 2010-14

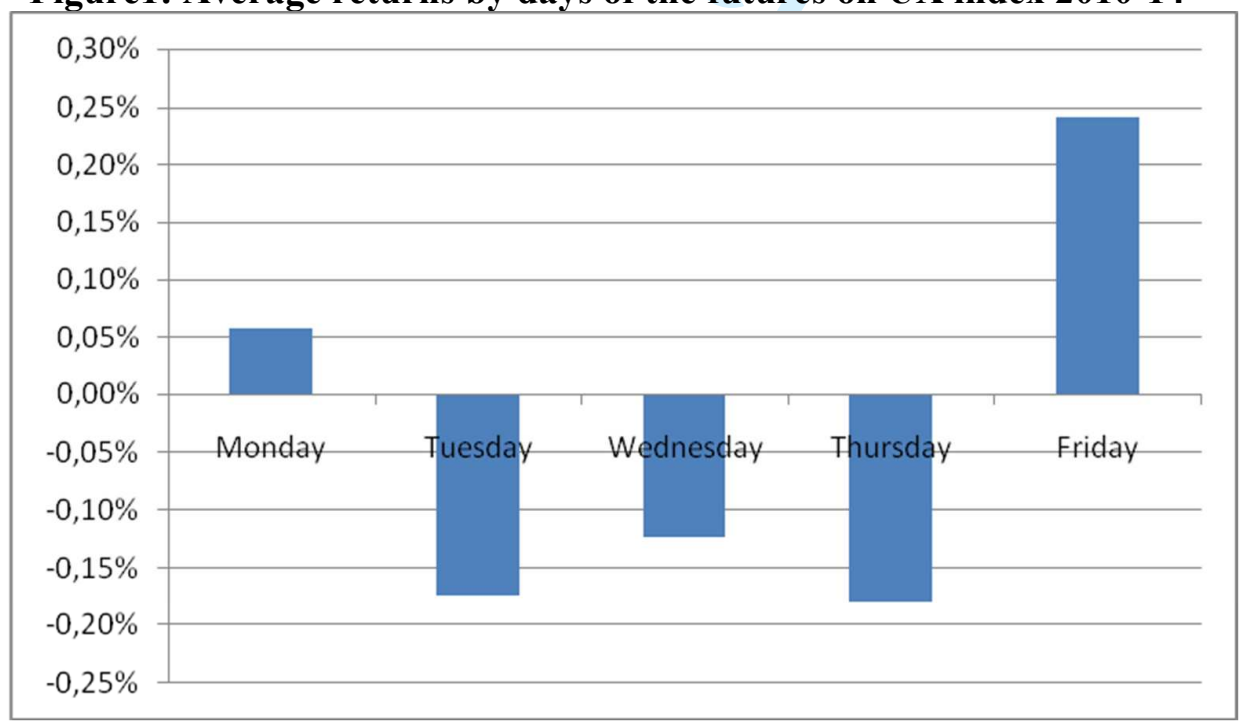


As can be seen, the biggest positive returns occur on Fridays. Returns are also positive on Mondays, but negative on the other days of the week. Therefore, there is preliminary evidence of a possible weekend effect. Next, we carry out some formal statistical tests as specified above.

The Student's t-test results are presented in Table 2.

Table 2: T-test of the daily returns for different days of the week for the futures on the UX index during 2010-2014

\begin{tabular}{|c|c|c|c|c|c|}
\hline Parameter & Monday & Tuesday & Wednesday & Thursday & Friday \\
\hline \multicolumn{6}{|c|}{ Population 1 (data without day of analysis) } \\
\hline Mean, $\%$ & $-0.06 \%$ & $0.00 \%$ & $-0.01 \%$ & $0.00 \%$ & $-0.11 \%$ \\
\hline Standard deviation, $\%$ & $2.01 \%$ & $2.16 \%$ & $2.21 \%$ & $2.23 \%$ & $2.21 \%$ \\
\hline Number of observations & 948 & 929 & 924 & 925 & 930 \\
\hline \multicolumn{6}{|c|}{ Population 1 (data for the day of analysis) } \\
\hline Mean, $\%$ & $0.06 \%$ & $-0.17 \%$ & $-0.12 \%$ & $-0.18 \%$ & $0.24 \%$ \\
\hline Standard deviation, $\%$ & $2.75 \%$ & $2.17 \%$ & $2.00 \%$ & $1.89 \%$ & $1.95 \%$ \\
\hline Number of observations & 216 & 235 & 240 & 239 & 234 \\
\hline \multicolumn{6}{|c|}{ T-test results } \\
\hline t-criterion & 0.59 & -1.10 & -0.73 & -1.28 & 2.39 \\
\hline $\mathrm{t}$-critical $(\mathrm{p}=0,95)$ & & & 1,96 & & \\
\hline Null hypothesis & $\begin{array}{c}\text { Not } \\
\text { rejected }\end{array}$ & $\begin{array}{c}\text { Not } \\
\text { rejected }\end{array}$ & $\begin{array}{c}\text { Not } \\
\text { rejected }\end{array}$ & $\begin{array}{l}\text { Not } \\
\text { rejected }\end{array}$ & $\begin{array}{c}\text { Not } \\
\text { rejected }\end{array}$ \\
\hline
\end{tabular}

They imply that the only day of the week with statistically significant abnormal returns is Friday, and therefore the presence of the weekend effect in the Ukrainian stock market is confirmed.

The multiple regression analysis shows that the only statistically significant dummy variable is the Friday one (see Table 3): its coefficient is positive, it is the biggest, and it is statistically significant at the $95 \%$ confidence level. However, the model does not appear to be entirely data congruent (see Appendix A). 
Table 3: Parameters of the multiply regression with dummy variables of daily returns for different days of the week for the futures on the UX index during 2010-2014

\begin{tabular}{|l|c|c|c|c|c|c|}
\hline & Value & $\begin{array}{c}\text { Standard } \\
\text { error }\end{array}$ & $\mathrm{t}$ & $\operatorname{Pr}>|\mathrm{t}|$ & $\begin{array}{c}\text { Lower bound } \\
(95 \%)\end{array}$ & $\begin{array}{c}\text { Upper bound } \\
(95 \%)\end{array}$ \\
\hline Intercept & -0.0017 & 0.0014 & -1.2174 & 0.2237 & -0.0045 & 0.0011 \\
\hline Monday & -0.0009 & 0.0020 & -0.4230 & 0.6724 & -0.0048 & 0.0031 \\
\hline Tuesday & 0.0014 & 0.0020 & 0.7103 & 0.4777 & -0.0025 & 0.0054 \\
\hline Wednesday & 0.0025 & 0.0020 & 1.2296 & 0.2191 & -0.0015 & 0.0064 \\
\hline Friday & $\underline{\mathbf{0 . 0 0 4 2}}$ & $\underline{\mathbf{0 . 0 0 2 0}}$ & $\underline{\mathbf{2 . 1 0 0 8}}$ & $\underline{\mathbf{0 . 0 3 5 9}}$ & $\underline{\mathbf{0 . 0 0 0 3}}$ & $\underline{\mathbf{0 . 0 0 8 2}}$ \\
\hline
\end{tabular}

Finally, we use fractional integration techniques to estimate the fractional differencing parameter $\mathrm{d}$ for each day of the week under the three standard parameterisations of no deterministic terms, an intercept, and an intercept with a linear time trend in order to see if there is any evidence of a weekend effect. The results are displayed in Table 4.

Table 4: Estimates of d based on fractional integration

\begin{tabular}{|c|c|c|c|}
\hline & No regressors & An intercept & A linear time trend \\
\hline Monday & $\mathbf{- 0 . 1 4}(\mathbf{- 0 . 2 3}, \mathbf{- 0 . 0 3})$ & $\mathbf{- 0 . 1 4}(\mathbf{- 0 . 2 3}, \mathbf{- 0 . 0 3})$ & $\mathbf{- 0 . 1 4}(\mathbf{- 0 . 2 3}, \mathbf{- 0 . 0 3})$ \\
\hline Tuesday & $0.03(-0.07,0.15)$ & $0.03(-0.07,0.15)$ & $0.00(-0.11,0.14)$ \\
\hline Wednesday & $-0.10(-0.18,0.01)$ & $-0.10(-0.19,0.01)$ & $-0.10(-0.19,0.01)$ \\
\hline Thursday & $0.06(-0.04,0.19)$ & $0.06(-0.04,0.19)$ & $0.06(-0.05,0.19)$ \\
\hline Friday & $-0.02(-0.09,0.09)$ & $-0.02(-0.10,0.09)$ & $-0.03(-0.12,0.08)$ \\
\hline
\end{tabular}

The lowest estimate of $d$ is found for Mondays (-0.14 for the returns, which implies a value of about 0.86 for the $\log$ prices). In fact, for this particular day of the week, the $\mathrm{I}(0)$ hypothesis is rejected in favour of anti-persistence $(\mathrm{d}<0$, or alternatively, mean reversion $(\mathrm{d}<1)$ in the $\log$ prices $)$, whilst it cannot be rejected for the remaining days of the week. The results presented in the table are based on white noise errors. Those allowing for autocorrelated (Bloomfield) errors are fairly similar; however, the confidence intervals are wider and the $\mathrm{I}(0)$ hypothesis cannot be rejected in any single case.

\section{Figure 3: Estimates of d based on a semi-parametric Whittle method}




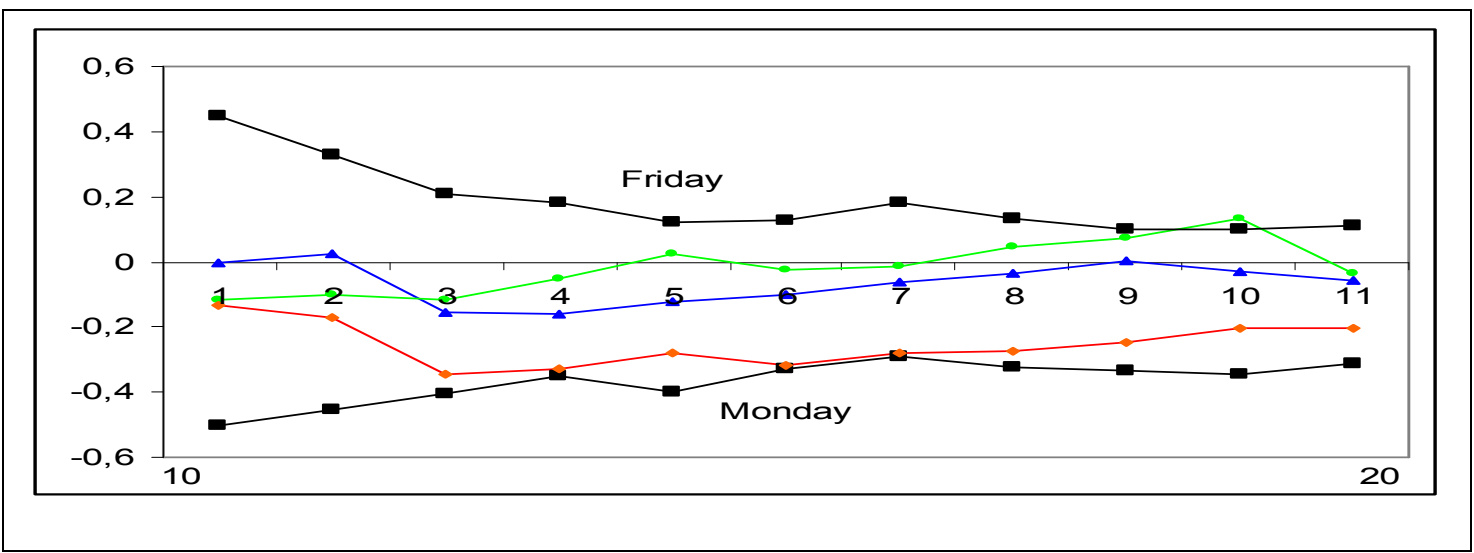

Figure 3 displays the semi-parametric estimates of $\mathrm{d}$ based on the Whittle function in the frequency domain (Robinson, 1995) for a selected range of values of $\mathrm{m}$, the bandwidth parameter, namely for $\mathrm{m}=10,11, \ldots, 20$, including the case of $\mathrm{m}=(\mathrm{T})^{0.5}$, often considered in empirical studies. The lowest estimates of $d$ are obtained on Mondays, while the highest ones are those for Fridays.

On the whole, our analysis suggests that the only day of the week with a statistically significant anomaly is Friday, when returns are abnormally high. Next we examine whether this can be exploited through appropriate trading strategies. The trading algorithm is quite simple and is based on the finding of abnormal positive returns on Fridays. This implies that a trader should open long positions in future contracts on the UX index. The only remaining question is when these positions should be closed. We consider different closing times, and therefore develop the following three trading strategies:

1) Strategy 1: "Friday close" - the position is closed at the end of the Friday.

2) Strategy 2: "Monday open"- the position is closed at the beginning of the Monday.

3) Strategy 3: "Monday close"- the position is closed at the end of the Monday.

We simulate trading future contracts on the UX index with a trading deposit of $500 \mathrm{UAH}$. The marginal requirements on these future contracts are 214 UAH per contract, therefore 
$500 \mathrm{UAH}$ is a sufficient deposit to trade with 1 future contract and cover possible drawdowns which may occur during trading.

The trading results for the different strategies are presented in Table 5. The dynamics of the equity of the trading deposit for different strategies during 2010-2014 is shown in Figure 3.

Table 5: Trading results for different strategies for the period 2010-2014

\begin{tabular}{|l|c|c|c|c|c|c|}
\hline Strategy & $\begin{array}{c}\text { Number } \\
\text { of trades }\end{array}$ & $\begin{array}{c}\text { Number of } \\
\text { successful } \\
\text { trades }\end{array}$ & $\begin{array}{c}\% \text { of } \\
\text { successful } \\
\text { trades }\end{array}$ & $\begin{array}{c}\text { Financial } \\
\text { result, } \\
\text { UAH }\end{array}$ & $\begin{array}{c}\text { Financial } \\
\text { result, \% }\end{array}$ & $\begin{array}{c}\text { Annual } \\
\text { financial } \\
\text { result, \% }\end{array}$ \\
\hline $\begin{array}{l}\text { Friday } \\
\text { close }\end{array}$ & 231 & 118 & $51.1 \%$ & 586 & $117.2 \%$ & $26.0 \%$ \\
\hline $\begin{array}{l}\text { Monday } \\
\text { open }\end{array}$ & 231 & 123 & $53.2 \%$ & 582 & $116.4 \%$ & $25.9 \%$ \\
\hline $\begin{array}{l}\text { Monday } \\
\text { close }\end{array}$ & 231 & 121 & $52.4 \%$ & 484 & $96.9 \%$ & $21.5 \%$ \\
\hline
\end{tabular}

Figure 3: Dynamics of the equity of the trading account for different strategies during 2010-2014

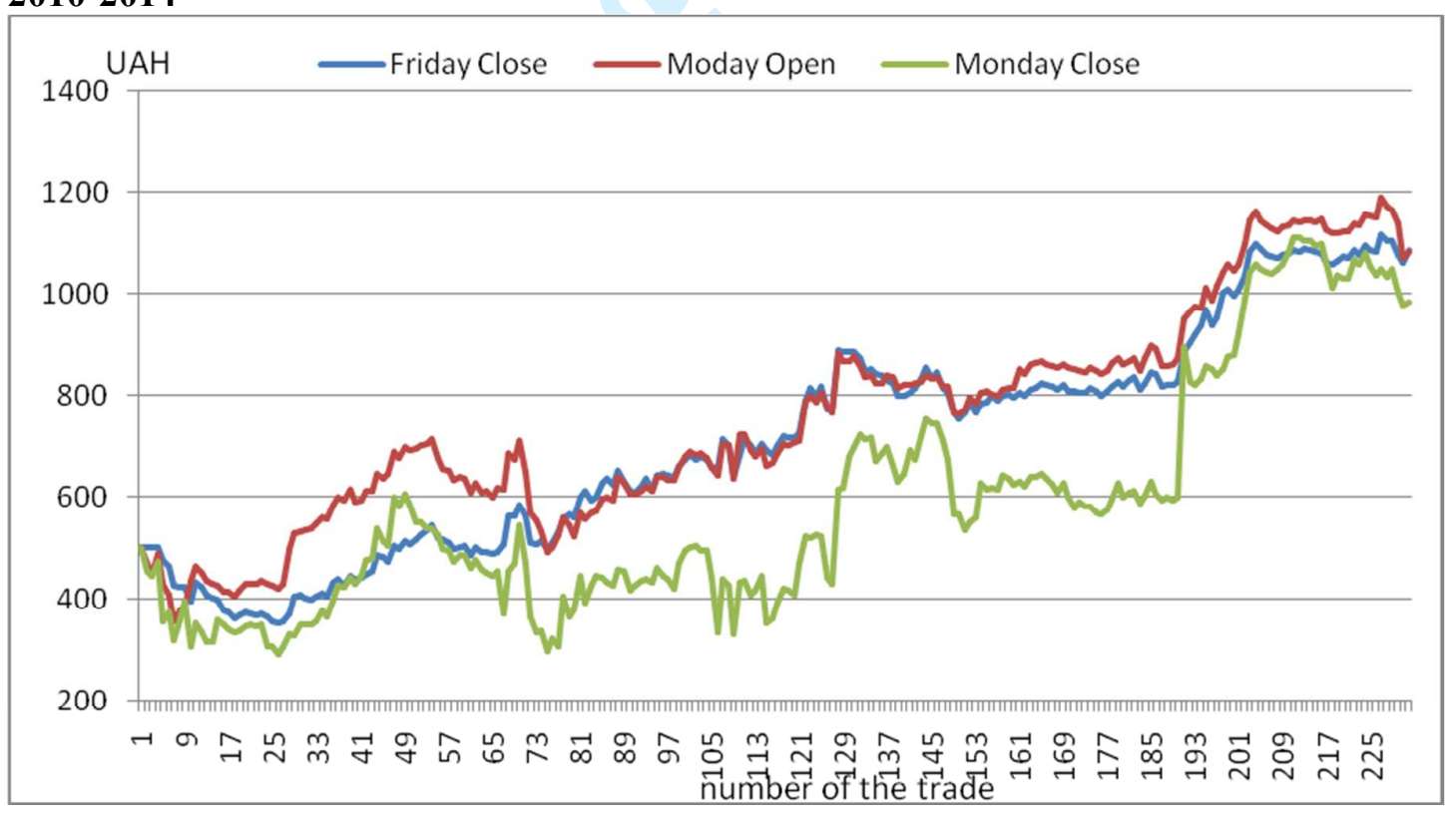

All three strategies appear to be profitable. The "Monday close" strategy is the least profitable and most volatile. The other two ("Friday close" and "Monday open"), produce positive profits in all cases (25\% annual profits), with an average of $2.5 \mathrm{UAH}$. However, the analysis does not incorporate transaction costs, such as spread, commissions per deal to 
the exchange and the broker, payments for money transfers and registering procedures. More precisely, the average net profit per trade becomes 1-1.5 UAH after taking into account the spread (on average 1 UAH per contract) and the commission per deal (between 0.5 and 1 UAH depending on type of the deal - short or long-term) - this is smaller than calculated before, but still positive given the available free margins and leverage strategies.

\section{Conclusions}

In this paper we have examined one of the most recognised anomalies, i.e. the weekend effect, in the Ukrainian stock market applying different methods to UX futures daily data. Using a wide range of statistical instruments (average analysis, regression analysis with the use of dummy variables, t-tests and fractional integration), we find some evidence of this anomaly in the form of positive returns on Fridays.

To examine whether or not this anomaly gives exploitable profit opportunities we have replicated the actions of a trader using trading algorithms based on the weekend effect. All the strategies considered appear to be profitable, especially that based on opening long positions on "Friday open" and closing them on "Friday close", which generates profits of up to $25 \%$ per year (excluding transaction costs) with no leverage in trading. Consequently, in the case of the Ukrainian stock market the weekend effect (positive returns on Friday) is not only a statistical anomaly but also an exploitable one, since abnormal profit can be made by trading with the UX index futures. This represents evidence of inefficiency for this particular market. 


\section{References}

Agrawal, A., Tandon, K., 1994, Anomalies or Illusions?Evidence from Stock Markets in Eighteen Countries.Journal of international Money and Finance, №13, 83-106.

Bloomfield, P., 1973, An exponential model in the spectrum of a scalar time series, Biometrika 60, 217-226.

Caporale, G.M., L.A. Gil-Alana, A. Plastun, and I. Makarenko, 2014, The Weekend Effect: A Trading Robot and Fractional Integration Analysis (May 2014). DIW Berlin Discussion Paper No. 1386. Available at SSRN:http://ssrn.com/abstract $=2456123$

Chen, H. and Singal, V., 2003, Role of Speculative Short Sales in Price Formation: The Case of the Weekend Effect. Journal of Finance.LVIII, 2.

Cross, F., 1973, The Behavior of Stock Prices on Fridays and Mondays. Financial Analysts Journal, November - December, 67-69.

Dahlhaus, R. (1989). Efficient parameter estimation for self-similar process. Annals of Statistics, 17, 1749-1766.

Fama, E.F., 1970, Efficient Markets: A Review of Theory and Empirical Work, Journal of Finance, 25, 2, 383-417.

Fortune, P., 1998, Weekends Can Be Rough: Revisiting the Weekend Effect in Stock Prices. Federal Reserve Bank of Boston.Working Paper No. 98-6.

Fortune, P., 1999, Are stock returns different over weekends? a jump diffusion analysis of the «weekend effect». New England Economic Review.3-19

French, K., 1980, Stock Returns and the Weekend Effect. Journal of Financial Economics. $8,1,55-69$.

Gibbons, M. and Hess, P., 1981, Day Effects and Asset Returns. Journal of Business, 54, no, 4, 579-596.

Kazemi, H. S., Zhai, W., He, J. and Cai, J., 2013, Stock Market Volatility, Speculative Short Sellers and Weekend Effect: International Evidence. Journal of Financial Risk Management.Vol.2, No. 3. 47-54.

Keim, D. B. and R. F. Stambaugh, 1984, A Further Investigation of the Weekend Effect in Stock Returns, Journal of Finance, Vol. 39 (July), 819-835.

Mendenhall, W., R. J. Beaver and B. M. Beaver, (2003), Introduction to Probability and Statistics, 11th edn, Brooks / Cole, Pacific Grove.

Olson, D., Chou, N. T., \& Mossman, C., 2011, Stages in the Life of the Weekend Effect http://louisville.edu/research/for-faculty-staff/reference-search/1999-references/2011business/olson-et-al-2011-stages-in-the-life-of-the-weekend-effect.

Racicot, F-É., 2011, Low-frequency components and the Weekend effect revisited: Evidence from Spectral Analysis. International Journal of Finance, 2, 2-19. 
Robinson, P.M., 1995, Gaussian semi-parametric estimation of long range dependence, Annals of Statistics 23, 1630-1661.

Rogalski, R. J., 1984, New Findings Regarding Day-of-the-Week Returns over Trading and Non-Trading Periods: A Note, Journal of Finance, Vol. 39, (December), 1603-1614.

Rystrom, D.S. and Benson, E., 1989, Investor psychology and the day-of-the-week effect. Financial Analysts Journal (September/October), 75-78.

Schwert, G. W., 2003, Anomalies and Market Efficiency.Handbook of the Economics of Finance. Elsevier Science B.V., Ch.5, 937-972.

Sias, R. W., Starks, L. T., 1995, The day-of-the week anomaly: the role of institutional investors. Financial Analyst Journal.May - June.58-67.

Singal, V. and Tayal, J. (2014) Does Unconstrained Short Selling Result in Unbiased Security Prices? Evidence from the Weekend Effect in Futures Markets (May 5, 2014). Available at SSRN: http://ssrn.com/abstract $=2433233$

Smirlock, M. and Starks, L., 1986, Day-of-the-Week and Intraday Effects in Stock Returns, Journal of Financial Economics, Vol. 17, 197-210. 


\section{Appendix A}

Results of the regression analysis for daily returns on different days of the week for the futures on the UX index during 2010-2014

Table A.1: Goodness of fit statistics:

\begin{tabular}{|c|c|}
\hline Observations & 995 \\
\hline Sum of weights & 995 \\
\hline DF & 990 \\
\hline R2 & 0.0080 \\
\hline Adjusted R & 0.0040 \\
\hline MSE & 0.0004 \\
\hline RMSE & 0.0201 \\
\hline DW & 1.8447 \\
\hline
\end{tabular}

Table A.2: Analysis of variance:

\begin{tabular}{|c|c|c|c|c|c|}
\hline Source & DF & $\begin{array}{c}\text { Sum of } \\
\text { squares }\end{array}$ & $\begin{array}{c}\text { Mean } \\
\text { squares }\end{array}$ & F & Pr> F \\
\hline Model & 4 & 0.0032 & 0.0008 & 1.9956 & 0.0931 \\
\hline Error & 990 & 0.3997 & 0.0004 & & \\
\hline Corrected Total & 994 & 0.4029 & & & \\
\hline
\end{tabular}




\title{
THE WEEKEND EFFECT: \\ AN EXPLOITABLE ANOMALY \\ IN THE UKRAINIAN STOCK MARKET?
}

\section{Revised, December 2015}

\begin{abstract}
This paper provides some new empirical evidence on the weekend effect (one of the best known anomalies in financial markets) in Ukrainian futures prices. The analysis uses various statistical techniques (average analysis, Student's ttest, dummy variables, and fractional integration) to test for the presence of this anomaly, and then a trading simulation approach to establish whether it can be exploited to make extra profits. The statistical evidence points to abnormal positive returns on Fridays, and a trading strategy based on this anomaly is shown to generate annual profits of up to $25 \%$. The implication is that the Ukrainian stock market is inefficient.
\end{abstract}

Keywords: Efficient Market Hypothesis; Weekend Effect; Trading Strategy.

JEL classification: $G 12$, C63 


\section{Introduction}

Since Fama (1970) introduced the Efficient Market Hypothesis (EMH), the behaviour of asset prices has been extensively investigated to establish whether it is consistent with this paradigm. Anomalies in the behaviour of financial markets, apparently inconsistent with the Efficient Market Hypothesis, have been investigated extensively in the last 30 years. However, the evidence is still inconclusive, different conclusions having been reached depending on the data and the methods used.

One of the best known anomalies is the so-called "day of the week" or weekend effect. Cross (1973) reported that asset prices tend to increase on Fridays and decrease on Mondays. A number of subsequent papers have tested for this anomaly (see, e.g., Sias and Starks, 1995; Schwert, 2003; Olson et al., 2011; Kazemi et al. 2013)) providing mixed evidence, but none has looked at the Ukrainian stock market, which is the focus of the present study.

The Ukrainian case is a very interesting one because of the very low level of market efficiency. According to Mynhardt et al. (2013), the Hurst exponent for the Ukrainian stock market equals $0.67,{ }^{1}$ a market being said to be efficient if the Hurst exponent is close to 0.5 - the more it deviates from the 0.5 the more inefficient the market is (see Caporale et al. 2014 for details). Our analysis uses various statistical techniques (average analysis, Student's t-tests, dummy variables, and fractional integration) to test for the presence of the "day of the week" or weekend anomaly, and then a trading simulation approach is applied to establish whether it can be exploited to make abnormal profits.

The results have implications both on a theoretical level (providing evidence about the relevance of the EMH) and on practical one (since they can be used to develop profitable trading strategies in the Ukrainian stock market exploiting the weekend effect).

\footnotetext{
${ }^{1}$ In the US stock market this value is 0.51 , in the UK 0.53 , in China 0.61 .
} 
Further, any evidence of inefficiency is useful to regulators of the stock exchange in Ukraine and to prevent informational asymmetry.

The layout of the paper is as follows. Section 2 briefly reviews the literature on the weekend effect. Section 3 describes the data and outlines the empirical methodology. Section 4 presents the empirical results, while Section 5 offers some concluding remarks.

\section{Literature Review}

Cross (1973) analysed Standard \& Poor's Composite Stock Index data from January 1953 to December 1970 and claimed to have found some patterns in the behaviour of US asset prices, namely an increase on Fridays and a decrease on Mondays. French (1980) extended this analysis to 1977 and reported negative returns on Mondays. Gibbons and Hess (1981), Keim and Stambaugh (1984), Rogalski (1984) and Smirlock and Starks (1986)also found the positive-Friday / negative-Monday pattern. Agrawal and Tandon (1994) examined 19 equity markets around the world, and found "day of the week" effects in most developed markets. Further evidence was provided by Olson et al. (2011), Racicot (2011), Singal and Tayal (2014), and Caporale et al. (2014), who found some evidence of the weekend effect in the US stock market, FOREX, and commodity markets as well as in the Russian stock market; in particular, fractional integration techniques suggest that the lowest orders of integration occur on Mondays.

Possible explanations for the weekend effect are: the psychology of investors who believe that Monday is a "difficult" day of the week and have a more positive perception of Friday (Rystrom and Benson, 1989); the closing of speculative positions on Fridays and the establishing of new short positions on Mondays by traders (Kazemi et al., 2013 and Chen and Singal, 2003), and the trading patterns of institutional investors (Sias and Starks, 1995). Another possible reason is that over the weekend market participants have more time to analyse price movements and, as a result, on Mondays a larger number of trades 
takes place. Alternatively, this might be due to deferred payments during the weekend, which create an extra incentive for the purchase of securities on Fridays, leading to higher prices on that day.

Evidence that the weekend effect has become less important over the years has been reported by Fortune (1998, 1999), Schwert (2003), and Olson et al. (2011). Further, Caporale et al. (2014) show that this anomaly cannot be exploited to make abnormal profits (and therefore it is not inconsistent with the EMH) by taking a trading robot approach. Most recently, Robins and Smith (2015) have claimedthat the weekendeffect has disappeared since markets have become more efficient. However, this might be the case in the developed markets, but not necessarily in the emerging ones, where anomalies might still play an important role.

The evidence is mixed. For example, Dharani and Natarajan (2013), Al-Jafari (2012), Abdalla (2012), Shamshir and Mustafa (2014), Aly, Mehdian, and Perry (2004) find that there is no weekend effect in the Indian Stock market, Omani stock market, Karachi stock exchange, Egyptian stock market respectively. On the other hand the weekend anomaly was detected by Abdullah et al. (2011) for the case of Kula Lumpur shariah index; Ulussever et al. (2011) in Saudi stock market; Al-Mutairi (2010) and AlLoughani and Chappell (2001) for the Kuwait stock exchange; Sutheebanjard and Premchaiswadi (2010) in the Thailand stock exchange; McGowan and Ibrihim (2009) in Russian stock market; Dicle and Hassan (2007) for the Istanbul stock exchange indices; Chukwuogor-Ndu (2007) in the East Asian financial markets and Choudhry (2000) in seven emerging Asian stock markets including India, Indonesia, Malaysia, The Philippine, South Korea, Taiwan, and Thailand. Al-Barrak (2009) tests the efficiency of the stock markets of Saudi Arabia, Kuwait, Dubai, and finds evidence in favour of the weekend effect only in Kuwait stock market. Marrett and Worthington (2008) find partial evidence 
in favour of this anomaly. The mixed evidence might be due to differences in the data and the methodology used.

\section{Data and methodology}

We use daily data for UX index futures, the Ukrainian Exchange being the biggest stock exchange in Ukraine in terms of trading volume. Futures are particularly interesting because they the relevant data can also be used to test trading strategies using simulation techniques. The sample covers the period from May 2010(the first available observation) to the end of December 2014. The data source is the Ukrainian Exchange (http://www.ux.ua/en/).

To examine whether there is a weekend effect we use the following techniques:

- $\quad$ average analysis

- $\quad$ Student's t-tests

- $\quad$ regression analysis with dummy variables

- fractional integration tests

Average analysis provides preliminary evidence on whether there are differences between returns on different days of the week.

Student's t-tests are carried out for the null hypothesis that returns on all days of the week belong to the same population; a rejection of the null implies a statistical anomaly in the price behavior on a specific day of the week. Given the size of our dataset, it is legitimate to argue that normality holds on the basis of the Central Limit Theorems (see Mendenhall, Beaver and Beaver, 2003), and therefore these are valid statistical tests. As a further check for normality, we also apply Pearson's criterion: we randomly select 100 consecutive UX index futures values for the period 2014 (Table 1) and calculate the critical value of the distribution. These confirm that the data are normally distributed and therefore 
1

2

3

4

5

6

7

8

9

10

Student's t-tests are valid, since their critical values do not exceed those of the chi-square distribution.

Table 1: "Normality" test of the UX index futures data

\begin{tabular}{|l|c|}
\hline \multicolumn{1}{|c|}{ Parameters } & Values \\
\hline Observations & 100 \\
\hline Average & 1233 \\
\hline Standard deviation & 65 \\
\hline Confidence level & 0.95 \\
\hline Chi-square values & 8.98 \\
\hline Chi-square distribution critical value & 11 \\
\hline Conclusion & Dataarenormallydistributed \\
\hline
\end{tabular}

The t-statistic is calculated as follows:

$$
t=\frac{\left|M_{1}-M_{2}\right|}{\sqrt{\frac{\sigma_{1}^{2}}{N_{1}}+\frac{\sigma_{2}^{2}}{N_{2}}}}
$$

where $M_{1} \quad-\quad$ mean of the population of returns on the day whose effects are being tested;

$M_{2} \quad-\quad$ mean of the population of all returns except the observations on the day whose effects are being tested;

$\sigma_{1}-s_{1}-$ standard deviation of the population of returns on the day whose effects are being tested;

$\sigma_{2} \quad-\quad$ standard deviation of the population of all returns except the observations on the day whose effects are being tested;

$N_{1} \quad-\quad$ size of the population of returns on the day whose effects are being tested;

$N_{2} \quad-\quad$ size of the population of all returns except the observations on the day whose effects are being tested $;^{2}$

\footnotetext{
${ }^{2}$ This is the day which is being analysed for the presence of an anomaly.
} 
The test is carried out at the $95 \%$ confidence level, and the degrees of freedom are $\mathrm{N}-1$ ( $\mathrm{N}$ being equal to $\mathrm{N}_{1}+\mathrm{N}_{2}$ ). Returns are computed as follows:

$$
\mathbf{R}_{\mathrm{i}}=\left(\frac{\text { Close }_{\mathrm{i}}}{\text { Open }_{\mathrm{i}}}-1\right) \times 100 \%
$$

where $R_{i} \quad-\quad$ UX index futures returns on the $i$-thday in $\%$;

$$
\text { Open }_{i} \text { - } \quad \text { open priceon thei-thday; }
$$

Close $_{i}-\quad$ close priceon thei-thday.

We also run multiple regressions including a dummy variable for each day of the week, specifically:

$$
\mathbf{Y}_{\mathrm{t}}=\mathbf{b}_{0}+\mathrm{b}_{1} \text { Monday } \mathrm{t}+\mathbf{b}_{2} \text { Tuesday }+\mathbf{b}_{3} \text { Wednesday }_{\mathrm{t}}+\mathrm{b}_{\mathrm{i}} \text { Friday }_{\mathrm{t}}+\varepsilon_{\mathrm{t}}
$$

where $Y_{t}$ - difference between average returns during a week and the dayof the week whose effects are being tested;

$\mathbf{b}_{0}$-difference between average returns during a week and on Thursdays (this is chosen as a typical day of the week, no anomalies in price behaviour have previously been detected on this day);

$\boldsymbol{b}_{\mathbf{n}}$ - difference between average returns on then-th day of the week included in the model and on Thursdays;

Monday $_{i}$-dummy variable for Monday, equal to 1 on that day of the week, and 0 otherwise.

The size, sign and statistical significance of the dummy coefficients provide information about possible anomalies on individual days of the week.

As an additional test, we estimate the degree of integration of the series for different days of the week. Specifically, we use the Whittle function in the frequency domain (Dahlhaus, 1989)in the following model:

$$
y_{t}=\alpha+\beta t+x_{t} ; \quad(1-L)^{d} x_{t}=u_{t},
$$


where $y_{t}$ is the observed time series; $\alpha$ and $\beta$ are the intercept and the coefficient on the linear trend respectively, $\mathrm{x}_{\mathrm{t}}$ is assumed to be an $\mathrm{I}(\mathrm{d})$ process where $\mathrm{d}$ can be any real number, and $\mathrm{u}_{\mathrm{t}}$ is assumed to be weakly $\mathrm{I}(0)$ autocorrelated. Rather than specifying a parametric ARMA model, we follow the non-parametric approach of Bloomfield (1973), which also produces autocorrelations decaying exponentially as in the AR case. If the estimated order of integration for a particular day, specifically Monday or Friday, is significantly different from that for the other days of the week, then it can be argued that there is evidence of a weekend effect.

Finally, having tested for possible weekend effects, we examine whether they give rise to exploitable profit opportunities by means of a trading simulation approach. Specifically, we use an algorithm based on the weekend effect to replicate the behaviour of a trader who opens positions on the UX futures and holds them for a certain period of time.

We use the following procedure to simulate the trading process. First we compute the percentage result of the deal:

$$
\text { \% result }=\frac{100 \% \times P_{\text {open }}}{P_{\text {close }}}
$$

where ${ }^{P_{\text {opt } n}}$ - opening price

$P_{\text {close }}$ - closing price

Then this difference is converted into Ukrainian hryvnas (UAH).

$$
\text { UAHresult }=\% \text { result } \times 1000
$$

where UAHresult - is result of the deal in UAH.

The sum of results from each deal in UAH is the total financial result of trading.

A strategy resulting in a number of profitable trades $>50 \%$ and positive total profits is defined as indicating an exploitable market anomaly. 


\section{Empirical results}

We start with some simple average analysis. The results are displayed in Figure 1.

Figure1: Average returns by days of the futures on UX index 2010-14

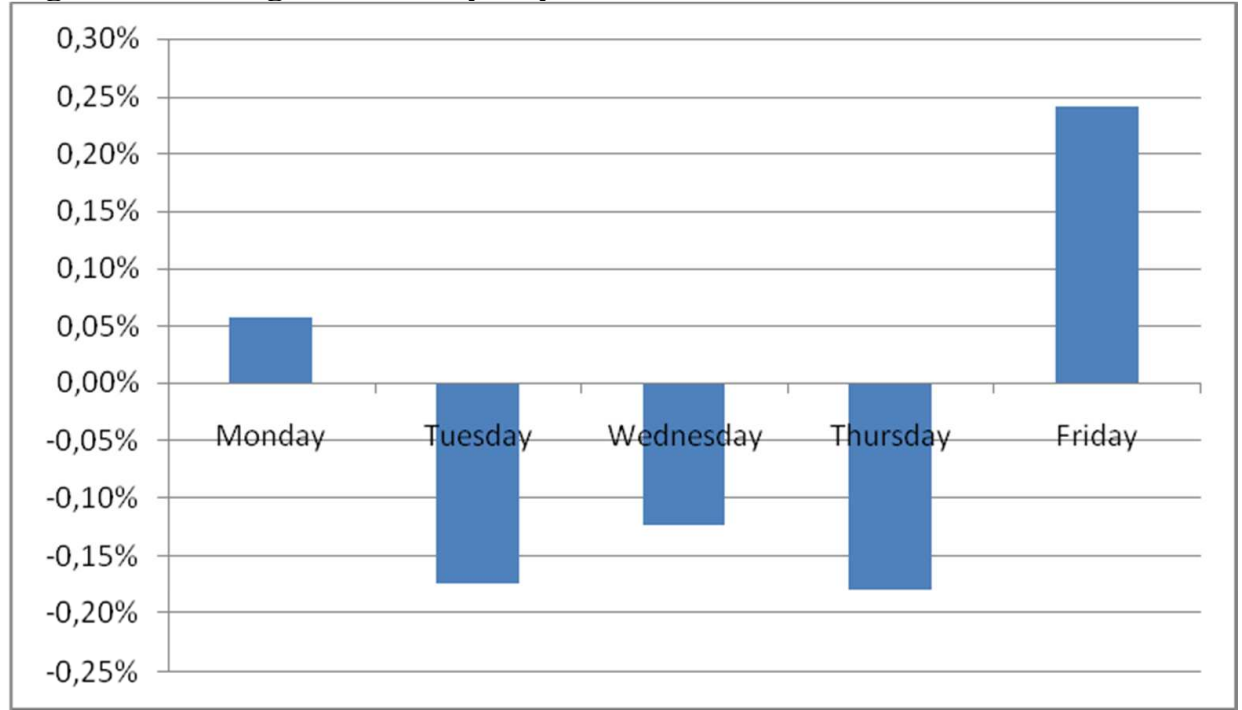

As can be seen, the biggest positive returns occur on Fridays. Returns are also positive on Mondays, but negative on the other days of the week. Therefore, there is preliminary evidence of a possible weekend effect. Next, we carry out some formal statistical tests as specified above.

The Student's t-test results are presented in Table 2.

Table 2: T-test of the daily returns for different days of the week for the futures on the UX index during 2010-2014

\begin{tabular}{|l|c|c|c|c|c|}
\hline \multicolumn{1}{|c|}{ Parameter } & Monday & Tuesday & Wednesday & Thursday & Friday \\
\hline \multicolumn{7}{|c|}{ Population 1 (data without day of analysis) } \\
\hline Mean, \% & $-0.06 \%$ & $0.00 \%$ & $-0.01 \%$ & $0.00 \%$ & $-0.11 \%$ \\
\hline Standard deviation, \% & $2.01 \%$ & $2.16 \%$ & $2.21 \%$ & $2.23 \%$ & $2.21 \%$ \\
\hline Number of observations & 948 & 929 & 924 & 925 & 930 \\
\hline
\end{tabular}


Table 3: Parameters of the multiply regression with dummy variables of daily returns for different days of the week for the futures on the UX index during 2010-2014

\begin{tabular}{|l|c|c|c|c|c|c|}
\hline & Value & Standarderror & $\mathrm{t}$ & $\operatorname{Pr}>|\mathrm{t}|$ & $\begin{array}{c}\text { Lowerbound } \\
(95 \%)\end{array}$ & $\begin{array}{c}\text { Upperbound } \\
(95 \%)\end{array}$ \\
\hline Intercept & -0.0017 & 0.0014 & -1.2174 & 0.2237 & -0.0045 & 0.0011 \\
\hline Monday & -0.0009 & 0.0020 & -0.4230 & 0.6724 & -0.0048 & 0.0031 \\
\hline Tuesday & 0.0014 & 0.0020 & 0.7103 & 0.4777 & -0.0025 & 0.0054 \\
\hline Wednesday & 0.0025 & 0.0020 & 1.2296 & 0.2191 & -0.0015 & 0.0064 \\
\hline Friday & $\mathbf{0 . 0 0 4 2}$ & $\underline{\mathbf{0 . 0 0 2 0}}$ & $\underline{\mathbf{2 . 1 0 0 8}}$ & $\underline{\mathbf{0 . 0 3 5 9}}$ & $\underline{\mathbf{0 . 0 0 0 3}}$ & $\mathbf{0 . 0 0 8 2}$ \\
\hline
\end{tabular}


Finally, we use fractional integration techniques to estimate the fractional differencing parameter $d$ for each day of the week under the three standard parameterisations of no deterministic terms, an intercept, and an intercept with a linear time trend in order to see if there is any evidence of a weekend effect. The results are displayed in Table 4.

Table 4: Estimates of $d$ based on fractional integration

\begin{tabular}{|c|c|c|c|}
\hline & No regressors & An intercept & A linear time trend \\
\hline Monday & $\mathbf{- 0 . 1 4}(\mathbf{- 0 . 2 3}, \mathbf{- 0 . 0 3})$ & $\mathbf{- 0 . 1 4}(\mathbf{- 0 . 2 3}, \mathbf{- 0 . 0 3})$ & $\mathbf{- 0 . 1 4}(\mathbf{- 0 . 2 3 ,}, \mathbf{- 0 . 0 3})$ \\
\hline Tuesday & $0.03(-0.07,0.15)$ & $0.03(-0.07,0.15)$ & $0.00(-0.11,0.14)$ \\
\hline Wednesday & $-0.10(-0.18,0.01)$ & $-0.10(-0.19,0.01)$ & $-0.10(-0.19,0.01)$ \\
\hline Thursday & $0.06(-0.04,0.19)$ & $0.06(-0.04,0.19)$ & $0.06(-0.05,0.19)$ \\
\hline Friday & $-0.02(-0.09,0.09)$ & $-0.02(-0.10,0.09)$ & $-0.03(-0.12,0.08)$ \\
\hline
\end{tabular}

The lowest estimate of $\mathrm{d}$ is found for Mondays (-0.14 for the returns, which implies a value of about 0.86 for the $\log$ prices). In fact, for this particular day of the week, the $\mathrm{I}(0)$ hypothesis is rejected in favour of anti-persistence $(\mathrm{d}<0$, or alternatively, mean reversion $(\mathrm{d}<1)$ in the $\log$ prices $)$, whilst it cannot be rejected for the remaining days of the week. The results presented in the table are based on white noise errors. Those allowing for autocorrelated (Bloomfield) errors are fairly similar; however, the confidence intervals are wider and the $\mathrm{I}(0)$ hypothesis cannot be rejected in any single case.

\section{Figure 2: Estimates of d based on a semi-parametric Whittle method}

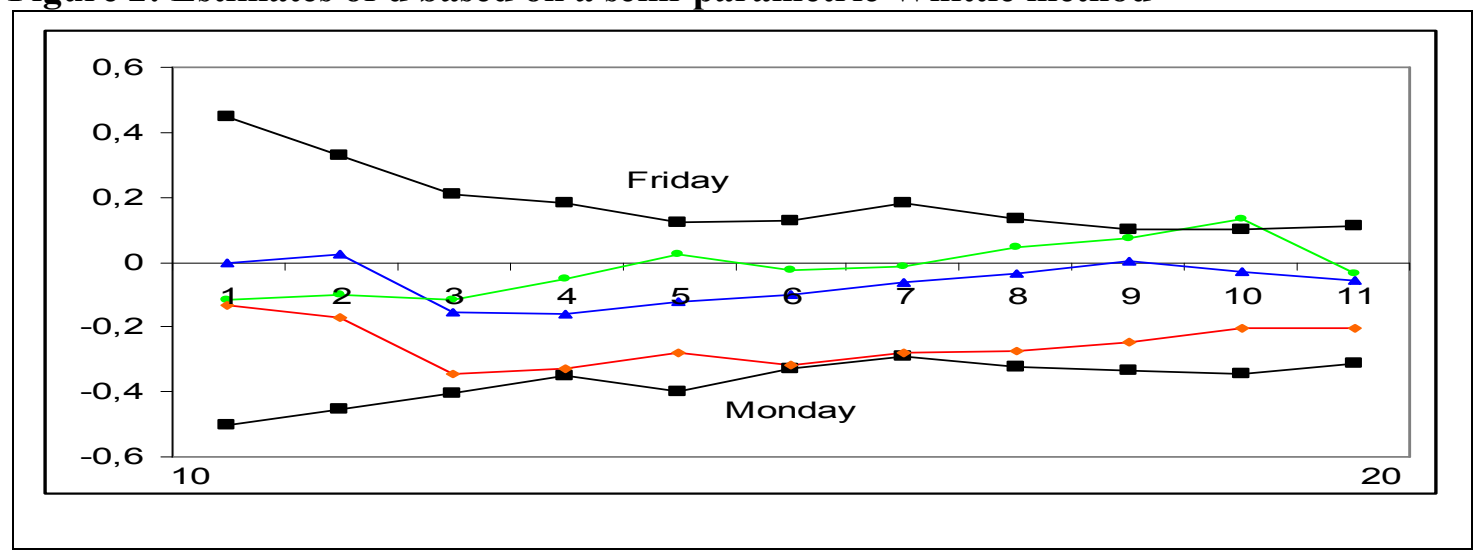


Figure 2 displays the semi-parametric estimates of $\mathrm{d}$ based on the Whittle function in the frequency domain (Robinson, 1995) for a selected range of values of $\mathrm{m}$, the bandwidth parameter, namely for $\mathrm{m}=10,11, \ldots, 20$, including the case of $\mathrm{m}=(\mathrm{T})^{0.5}$, often considered in empirical studies. The lowest estimates of $d$ are obtained on Mondays, while the highest ones are those for Fridays.

On the whole, our analysis suggests that the only day of the week with a statistically significant anomaly is Friday, when returns are abnormally high. Next we examine whether this can be exploited through appropriate trading strategies. The trading algorithm is quite simple and is based on the finding of abnormal positive returns on Fridays. This implies that a trader should open long positions in future contracts on the UX index on Friday open. The only remaining question is when these positions should be closed. We consider different closing times, and therefore develop the following three trading strategies:

1) Strategy 1: "Friday close" - the position is closed at the end of the Friday.

2) Strategy 2: "Monday open"- the position is closed at the beginning of the Monday.

3) Strategy 3: "Monday close"- the position is closed at the end of the Monday.

We simulate trading future contracts on the UX index with a trading deposit of $500 \mathrm{UAH}$. The marginal requirements on these future contracts are 214 UAH per contract, therefore $500 \mathrm{UAH}$ is a sufficient deposit to trade with 1 future contract and cover possible drawdowns which may occur during trading.

The trading results for the different strategies are presented in Table 5. The dynamics of the equity of the trading deposit for different strategies during 2010-2014 is shown in Figure 3. 
Table 5: Trading results for different strategiesfor the period 2010-2014

\begin{tabular}{|l|c|c|c|c|c|c|}
\hline & $\begin{array}{c}\text { Number } \\
\text { of trades }\end{array}$ & $\begin{array}{c}\text { Number of } \\
\text { successful } \\
\text { trades }\end{array}$ & $\begin{array}{c}\% \text { of } \\
\text { successful } \\
\text { trades }\end{array}$ & $\begin{array}{c}\text { Financial } \\
\text { result, } \\
\text { UAH }\end{array}$ & $\begin{array}{c}\text { Financial } \\
\text { result, \% }\end{array}$ & $\begin{array}{c}\text { Annual } \\
\text { financial } \\
\text { result, \% }\end{array}$ \\
\hline $\begin{array}{l}\text { Friday } \\
\text { close }\end{array}$ & 231 & 118 & $51.1 \%$ & 586 & $117.2 \%$ & $26.0 \%$ \\
\hline $\begin{array}{l}\text { Monday } \\
\text { open }\end{array}$ & 231 & 123 & $53.2 \%$ & 582 & $116.4 \%$ & $25.9 \%$ \\
\hline $\begin{array}{l}\text { Monday } \\
\text { close }\end{array}$ & 231 & 121 & $52.4 \%$ & 484 & $96.9 \%$ & $21.5 \%$ \\
\hline
\end{tabular}

Figure 3: Dynamicsof the equity of the trading account for different strategies during 2010-2014

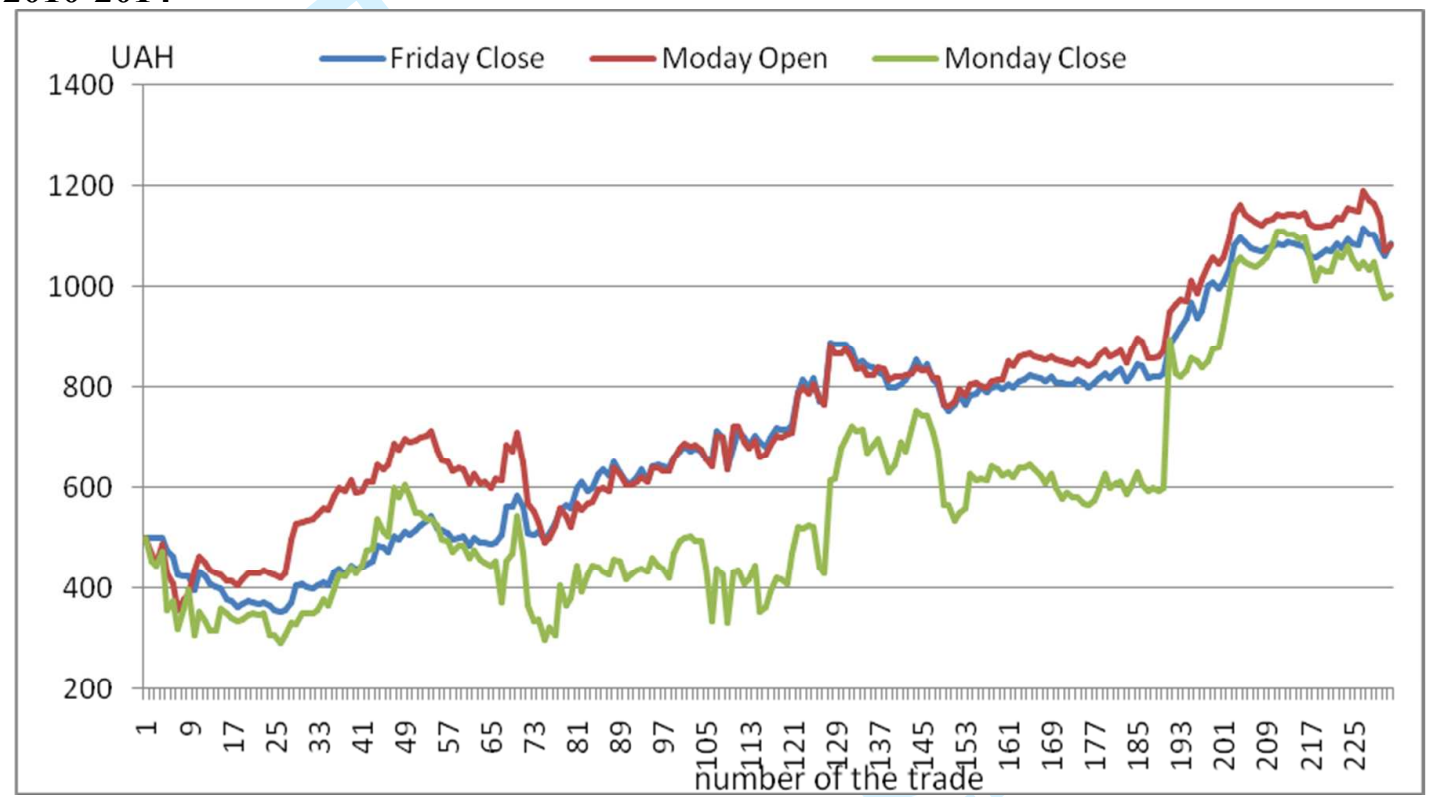

All three strategies appear to be profitable. The "Monday close" strategy is the least profitable and most volatile. The other two ("Friday close" and "Monday open"), produce positive profits in all cases (25\% annual profits), with an average of $2.5 \mathrm{UAH}$. However, the analysis does not incorporate transaction costs, such as spread, commissions per deal to the exchange and the broker, payments for money transfers and registering procedures. More precisely, the average net profit per trade becomes 1-1.5 UAH after taking into account the spread (on average 1 UAH per contract) and the commission per deal (between 0.5 and 1 UAH depending on type of the deal - short or long-term) - this is smaller than calculated before, but still positive given the available free margins and leverage strategies. 
As can be seen empirical results clearly evidence in favor of the weekend effect existence. Ukrainian stock market is influenced by the weekend effect mostly because of low efficiency of the market. A variety of problems (regulatory, methodological, infrastructural), taken together, form a negative synergetic effect and cause low efficiency of the market. The main factors causing the inefficiency of the Ukrainian stock market are: bad market infrastructure (undeveloped depositary and clearing institutions, low number of market makers); low liquidity and limited number of financial instruments; high volatility and risks; stock market is very small as well as trading volumes; low transparency and information disclosure in financial market; etc. Their solution will provide possibilities for the further development of the market increasing its efficiency.

The most actual public policy actions nowadays to improve Ukrainian stock market efficiency are:

- Formation of a favorable investment climate for foreign investors in Ukraine;

- Harmonization of national legislation with international standards and their implementation in the Ukrainian stock market;

- Coordination of activity between different state regulators of the financial market in Ukraine;

- Securities taxation facilitation (remove double taxation of investment income of non-residents, taxation of dividends, etc.);

- Internet-trading development and electronic documentary among stock market participants;

- Implementation of new financial instruments with various combinations of risk, liquidity and profitability parameters adapted to the needs of consumers of financial products; 
- Improving the quality of disclosure in the financial market by its participants, on the basis of generally accepted IFRS;

- $\quad$ Efficient transparency control system of activity in Ukrainian stock market.

\section{Conclusions}

In this paper we have examined one of the most recognised anomalies, i.e. the weekend effect, in the Ukrainian stock market applying different methods to UX futures daily data. Using a wide range of statistical instruments (average analysis, regression analysis with the use of dummy variables, t-tests and fractional integration), we find some evidence of this anomaly in the form of positive returns on Fridays.

To examine whether or not this anomaly gives exploitable profit opportunities we have replicated the actions of a trader using trading algorithms based on the weekend effect. All the strategies considered appear to be profitable, especially that based on opening long positions on "Friday open" and closing them on "Friday close", which generates profits of up to $25 \%$ per year (excluding transaction costs) with no leverage in trading. Consequently, in the case of the Ukrainian stock marketthe weekend effect (positive returns on Friday) is not only a statistical anomaly but also an exploitable one, since abnormal profit can be made by trading with the UX index futures. This represents evidence of inefficiency for this particular market.

These findings are important in several respects. First, they suggest that the EMH might be less relevant in the case of emerging markets such as Ukraine, where efficiency is still a long way from being achieved. Second, they are useful to market participants since they imply that it is possible to obtain abnormal profits in the Ukrainian stock market by exploiting the weekend effect anomaly. Third, they are informative for policy-makers and regulators aiming to design appropriate policy and frameworks to boost growth through financial development without compromising economic and financial stability. 


\section{References}

Abdalla, S., 2012, Day-of-the-week effect on returns and conditional volatility: Empirical evidence from Sudanese stock market. Middle Eastern Finance and Economics, 16, 167180.

Abdullah, R., N. Baharuddin, N.Shamsudin, W.Mahmood, and Z. Sahudin, 2011, The day of the week effect on Bursa (Bourse) Malaysia Shariah-compliant market. Interdisciplinary Journal of Research in Business, 1(4), 29-36.

Agrawal, A. and K.Tandon, 1994, Anomalies or illusions? Evidence from stock markets in eighteen countries. Journal of International Money and Finance, №13, 83-106.

Al-Barrak, A. M., 2009, Day-of-the-week effect in some of Gulf Cooperation Council (GCC) stock markets. Scientific Journal of King Faisal University (Humanities and Management Sciences), 10(2), 255-265.

Al-Jafari, M. K., 2012, An Empirical Investigation of the Day-of-the-Week Effect on Stock Returns and Volatility: Evidence from Muscat Securities Market. International Journal of Economics and Finance, 4(7), 141.

Al-Loughani, N., and D. Chappell, 2001, Modelling the day-of-the-week effect in Kuwait stock exchange: a non-linear GARCH representation. Applied Financial Economics, 11(4), 353-359.

Al-Mutairi, A., 2010, An investigation of the day of the week effect in the Kuwait stock exchange. Research Journal of International Studies, 16, 191-197.

Aly, H., S. Mehdian, and M. Perry, 2004, An analysis of day-of-the-week effects in the Egyptian stock market. International Journal of Business, 9(3), 301-30.

Bloomfield, P., 1973, An exponential model in the spectrum of a scalar time series, Biometrika 60, 217-226.

Caporale, G.M., L.A. Gil-Alana, A. Plastun, and I. Makarenko, 2014, The weekend effect: A trading robot and fractional integration analysis (May 2014). DIW Berlin Discussion Paper No. 1386. Available at SSRN:http://ssrn.com/abstract=2456123

Caporale, G.M., L.A. Gil-Alana, A. Plastun, and I. Makarenko, 2014, Long Memory in the Ukrainian Stock Market and Financial Crises. Journal of Economics and Finance. Available at http://dx.doi.org/10.1007/s12197-014-9299-x.

Chen, H. and V. Singal, 2003, Role of speculative short sales in price formation: The case of the weekend effect. Journal of Finance.58, 685-705.

Choudhry, T., 2000, Day of the week effect in emerging Asian stock markets: Evidence from the GARCH model. Applied Financial Economics, 10(3), 235-242.

Chukwuogor-Ndu, C., 2007, Day-of-the-week effect and volatility in stock returns: Evidence from East Asian financial markets. The International Journal of Banking and Finance, 5(1), 153-164. 
Cross, F., 1973, The behavior of stock prices on Fridays and Mondays. Financial Analysts Journal, November - December, 67-69.

Dahlhaus, R., 1989, Efficient parameter estimation for self-similar process. Annals of Statistics, 17, 1749-1766.

Dharani, M. and P. Natarajan, 2013, The Day of the Week Effect on Shariah Index Return in Indian Capital Market. Business Confluence Loyola Journal of Commerce, 1(1), 29-42.

Dicle, M., and M. K. Hassan, 2007, Day of the week effect in Istanbul stock exchange. Scientific Journal of Administrative Development, 5, 53-83.

Fama, E.F., 1970, Efficient markets: A review of theory and empirical work, Journal of Finance, 25, 2, 383-417.

Fortune, P., 1998, Weekends can be rough: Revisiting the weekend effect in stock prices. Federal Reserve Bank of Boston. Working Paper No. 98-6.

Fortune, P., 1999, Are stock returns different over weekends? a jump diffusion analysis of the «weekend effect». New England Economic Review.3-19

French, K., 1980, Stock returns and the weekend effect. Journal of Financial Economics. 8, $1,55-69$.

Gibbons, M. and Hess, P., 1981, Day effects and asset returns. Journal of Business, 54, 4, 579-596.

Kazemi, H. S., W. Zhai, J. He, and J. Cai, 2013, Stock market volatility, speculative short sellers and weekend effect: International evidence. Journal of Financial Risk Management.Vol.2, 3, 47-54.

Keim, D. B. and R. F. Stambaugh, 1984, A further investigation of the weekend effect in stock returns, Journal of Finance, 39, 819-835.

Marrett, G. J., and A. C. Worthington, 2009, An empirical note on the holiday effect in the Australian stock market, 1996-2006. Applied Economics Letters, 16(17), 1769-1772.

McGowan, Jr., C. B., and I. Ibrihim, 2009, An analysis of the day-of-the-week effect in the Russian stock market. International Business and Economics Research Journal, 8(9), 2530.

Mendenhall, W., R. J. Beaver and B. M. Beaver, 2003, Introduction to Probability and Statistics, 11th edn, Brooks / Cole, Pacific Grove.

Mynhardt, Ronald. H., Alex Plastun, and Inna Makarenko, 2013, Behavior of Financial Markets Efficiency during the Financial Market Crisis: 2007-2009. Corporate Ownership and Control, 11:2, 473-488.

Olson, D., Chou, N. T., and Mossman, C., 2011, Stages in the life of the weekend effect http://louisville.edu/research/for-faculty-staff/reference-search/1999-references/2011business/olson-et-al-2011-stages-in-the-life-of-the-weekend-effect. 
Racicot, F-É., 2011, Low-frequency components and the weekend effect revisited: Evidence from Spectral Analysis. International Journal of Finance, 2, 2-19.

Robinson, P.M., 1995, Gaussian semi-parametric estimation of long range dependence, Annals of Statistics 23, 1630-1661.

Robins, Russell P. and Geoffrey Peter, Smith, 2015, No More Weekend Effect. Critical Finance Review, Forthcoming. Available at SSRN: http://ssrn.com/abstract=2610172

Rogalski, R. J., 1984, New findings regarding day-of-the-week returns over trading and non-trading periods: A note, Journal of Finance, Vol. 39, (December), 1603-1614.

Rystrom, D.S. and E. Benson, 1989, Investor psychology and the day-of-the-week effect. Financial Analysts Journal (September/October), 75-78.

Schwert, G. W., 2003, Anomalies and market efficiency. Handbook of the Economics of Finance. Elsevier Science B.V., Ch.5, 937-972.

Shamshir M. and M. Khalid, 2014, Presence of Day-of-the-Week Effect in the Karachi Stock Market. ResearchJournalofFinanceandAccounting,Vol.5, No.19, 46-58.

Sias, R. W., Starks, L. T., 1995, The day-of-the week anomaly: the role of institutional investors. Financial Analyst Journal.May - June.58-67.

Singal, V. and Tayal, J. (2014) Does unconstrained short selling result in unbiased security prices? Evidence from the weekend effect in futures markets (May 5, 2014). Available at SSRN: http://ssrn.com/abstract $=2433233$

Smirlock, M. and Starks, L., 1986, Day-of-the-week and intraday effects in stock returns, Journal of Financial Economics, Vol. 17, 197-210.

Sutheebanjard, P., and W. Premchaiswadi, 2010, Analysis of calendar effects: Day-of-theweek effect on the stock exchange of Thailand (SET). International Journal of Trade, Economics and Finance, 1(1), 57-62.

Ulussever, T., I. GuranYumusak, and M. Kar, 2011,The day-of-the-week effect in the Saudi stock exchange: A non-linear GARCH Analysis. Journal of Economics and Social Studies, 1(1), 9-23. 


\section{Appendix A}

Results of the regression analysis for daily returns on different days of the week for the futures on the UX index during 2010-2014

Table A.1: Goodness of fit statistics:

\begin{tabular}{|c|c|}
\hline Observations & 995 \\
\hline Sumofweights & 995 \\
\hline DF & 990 \\
\hline R2 & 0.0080 \\
\hline Adjusted R & 0.0040 \\
\hline MSE & 0.0004 \\
\hline RMSE & 0.0201 \\
\hline DW & 1.8447 \\
\hline
\end{tabular}

Table A.2: Analysis of variance:

\begin{tabular}{|c|c|c|c|c|c|}
\hline Source & DF & Sumofsquares & Meansquares & F & Pr $>$ F \\
\hline Model & 4 & 0.0032 & 0.0008 & 1.9956 & 0.0931 \\
\hline Error & 990 & 0.3997 & 0.0004 & & \\
\hline CorrectedTotal & 994 & 0.4029 & & & \\
\hline
\end{tabular}

